Care:Jurnal Ilmiah Ilmu Kesehatan Vol.8, No.3, 2020, hal 369-382

Tersedia online di https://jurnal.unitri.ac.id/index.php/care

ISSN2527-8487(online)

ISSN2089-4503(cetak)

\title{
GAMBARAN ASUPAN NUTRISI DIMASA PANDEMI PADA MAHASISWA
}

\author{
Novita Dewi ${ }^{1)}$, Neni Memunah ${ }^{2)}$, Ronasari Mahaji Putri ${ }^{3)}$ \\ 1),2),3)Fakultas Ilmu Kesehatan, Universitas Tribhuwana Tunggadewi Malang \\ E-mail:novita1unitri@gmail.com
}

\begin{abstract}
Nutritional intake is needed by every buman being to fulfill bis survival. Proper nutrition results in the fulfillment of nutrients so that they can fight the COVID-19 virus. Covid-19 is at risk for students, most of whom are still dependent on their parents. The aim of the study was to describe the nutritional intake during the pandemic for students. This study uses an exploratory narrative method, with a cross-sectional approach. The instrument is a geogle form. Sampling by purposive sampling. The results showed that respondents in the second semester were 18 people (52.9\%), respondents aged 20-22 years were 27 people $(79 \%)$, respondents had an allowance of $<1.5$ million as many as 33 people $(97 \%)$ rarely consumed nutritious foods. Respondents in semester 6 were 26 people (52\%), respondents aged 20-22 years were 34 people (68\%), respondents had an allowance of $<1.5$ million, as many as 47 people (94\%) rarely consumed fruit vegetables every day. Respondents in semester 6 were 22 people (51.2\%), aged 20-22 years, 32 people (74.4\%) respondents had an allowance of $<1.5$ million, 14 people (100\%) consumed vitamins. Conclusion: Most of the respondents in semester 2, aged 20-22 years, have an allowance of $<1.5$ million, rarely consume nutritious food, most respondents in semester 6 and aged 20-22 years, almost all have an allowance of $<1.5$ million, rarely consume fruit vegetables every time. days, most respondents in semester 6 and aged 20-22 years, almost all have an allowance of $<1.5$ million rarely consume vitamins. The recommendations of the next researchers examined the relationship between fruit vegetable intake and the incidence of DM symptoms.
\end{abstract}

Keyword: Nutrition; nutritious food; consumption of fruits and vegetables; vitamins.

\begin{abstract}
ABSTRAK
Asupan nutrisi dibutuhkan setiap manusia untuk memenuhi keberlangsungan hidupnya. Nutrisi yang tepat mengakibatkan terpenuhinya zat giziehingga dapat melawan virus COVID-19. Covid-19 beresiko terjadi pada mahasiswa, sebagian besar masih tergantung pada orangtuanya. Tujuan penelitian mengetahui gambaran asupan nutrisi dimasa pandemi pada mahasiswa. Penelitian ini menggunakan metode narasi eksploratif, dengan pendekatan crossectional. Instrumen berupa geogle form. Pengambilan sampel secara purposive sampling.Hasil penelitian didapatkan responden semester 2 sebanyak 18 orang $(52.9 \%)$, responden berusia 20-22 tahun sebanyak 27 orang $(79 \%)$, responden memiliki uang saku $<1.5$ juta sebanyak 33 orang (97\%)jarang mengkonsumsi makanan yang bergizi. Responden semester 6 sebanyak 26 orang(52\%), responden berusia 20-22 tahun sebanyak 34 orang (68\%),
\end{abstract}

Cara mengutip: Dewi, Novita., Maemunah, Neni., \& Putri, M. Ronasari. (2020). Gambaran Asupan Nutrisi di Masa Pandemi pada Mahasiswa.Care:Jurnal Ilmiah Ilmu Kesehatan, 8(3), 369-382

Retrieved from https://jurnal.unitri.ac.id/index.php/care/article/view/1959 
responden memiliki uang saku $<1.5$ juta seanyak 47 orang $(94 \%)$ jarang mengkonsumsi sayuran buah setiap hari. Responden semester 6 sebanyak 22 orang (51.2\%), berusia 20-22 tahun sebesar 32 orang $(74.4 \%)$ responden memiliki uang saku $<1.5$ juta sebesar 14 orang $(100 \%)$ mengkonsumsi vitamin. Kesimpulan sebagian besar responden semester 2, berusia 20-22 tahun, memiliki uang saku $<1.5$ juta jarang mengkonsumsi makanan bergizi, sebagian besar responden semester 6 dan berusia berusia 20-22 tahun, hampir seluruhnya memiliki uang saku $<1.5$ juta jarang mengkonsumsi sayuran buah setiap hari, sebagian besar responden semester 6 dan berusia berusia 20-22 tahun, hampir seluruhnya memiliki uang saku $<1.5$ juta jarang mengkonsumsi vitamin. Rekomendasi peneliti berikutnya meneliti hubungan asupan sayuran buah dengan kejadian tanda gejala DM.

Kata Kunci: Nutrisi; makanan bergizi; konsumsi buah sayur; vitamin.

\section{PENDAHULUAN}

Pandemik COVID-19, memerlukan perhatian yang serius, utamanya di bidang kesehatan. Identifikasi dan sequencing SARS-CoV-2 diawal Januari 2020 sebagai coronavirus baru penyebab COVID-19 (Chan, et al., 2020, Huang, et al., 2020).Menurut WHO Maret 2020 dilaporkan 1 juta kasus dan yang meninggal 75.000 (Ayres, 2020).

Penderita COVID-19 positif jika sistem kekebalan imun menurun, sehingga virus menyerang dalam tubuh sehingga timbul beberapa gejala penyakit, seperti suhu $38^{\circ} \mathrm{C}$, adanya batuk kering, hingga sesak nafas berakibat kematian (Hui, D, et al, 2020). Kematian yang meningkat tersebut menyebabkan berbagai upaya untuk mengatasinya salah satunya dengan meningkatkan imunitas tubuh.

Penanganan virus tersebut bergantung pola hidup maupun pola kesehatannya
(Izazi, Kusuma, 2020).Kesehatan akan optimal jika fungsi sel berjalan dengan baik, perawatannya diperankan oleh nutrisi. Respon imun yang efektif melawan pathogen, mengatasi respon dengan cepat, untuk menghilangkan peradangan kronis yang mendasarinya. Kondisi kurang gizi mengakibatkan pertahanan tubuh lemah, mudahinfeksi (Alwarawrah, Kiernan, MacIver, 2018, Zhang, Liu,2020), berakibat kematian dini $70 \%$, disebabkan oleh anemia maupum hipertensi, berlanjut ke stroke (Aritonang, 2012),serupa jika nutrisi yang berlebihan dengan tanda Indeks Massa Tubuh (IMT) yang tinggi (kegemukan) berakibat peradangan berlebihan, mudah infeksi contoh influenza, lebih berisiko komplikasi (Alwarawrah, Kiernan, MacIver, 2018) penyakit akan lebih parah (Liu, He, Liu, et al. 2020). Komplikasi dapat dicegah dengan pencegahan terjangkit virus. 
Pencegahan terjangkitnya COVID-19 dengan membangun imunitas tubuh (Wulan \& Agusni, 2015, Susilo, et al., 2020), dilakukan dengan asupan nutrisi yang tepat, berupa pada sayuran mengandung mineral, vitamin maupun senyawa bioaktif yang terdapat (Siswanto \& Ernawati, 2013). Menurut Kemenkes (2020) panduan menyatakan menjaga konsumsi makanan bergizi seimbang, batasi pemakaian garam dan lemak, konsumsi suplemem dan multi vitamin jika diperlukan, hindari rokok dan minuman berakohol.

Berdasarkan fenomena adanya asupan nutrisi yang terbatas pada mahasiswa. Terhambatnya pengiriman biaya hidup mengalami penurunan maupun keterlambatan dimungkinkan asupan nutrisi yang berkurang. Maka peneliti penting melaksanakan penelitian untuk mengetahui”. Gambaran asupan nutrisipada masa pandemi pada mahasiswa".

\section{METODE PENELITIAN}

Penelitian gambaran asupan nutrisi menggunakan pendekatan crossectional, desain penelitian diskristif analitik. Sampel 108 dari 400 populasi mahasiswa dengan tehnik purposif sampling. Kriteria inklusi meliputi mahasiswa yang sehat, eksklusi meliputi, mahasiswa yang tidak memiliki akses internet, sakit. instrumen yang digunakan geogle form. Pelaksanaan penelitian bulan Maret 2020 .

\section{HASIL}

Tabel 1 Distribusi frekuensi karakteristik data umum responden

\begin{tabular}{lll}
\hline Data & f & $\mathbf{( \% )}$ \\
\hline Semester & 44 & 40.7 \\
4 & & \\
6 & 60 & 55.6 \\
8 & 4 & 3.7 \\
\hline Total & $\mathbf{1 0 8}$ & $\mathbf{1 0 0 . 0}$ \\
\hline Usia & 11 & 10.2 \\
$17-19$ tahun & & \\
$20-22$ tahun & 80 & 74.1 \\
$23-25$ tahun & 16 & 14.8 \\
25 tahun ke atas & 1 & .9 \\
\hline Total & $\mathbf{1 0 8}$ & $\mathbf{1 0 0 . 0}$ \\
\hline Uang saku & 102 & 94.4 \\
$<1,5$ juta & & \\
$>1,5$ juta & 6 & 5.6 \\
\hline Total & $\mathbf{1 0 8}$ & $\mathbf{1 0 0 . 0}$ \\
\hline
\end{tabular}

Berdasarkan Tabel 1 dapat diketahui bahwa sebagian besar respondensemester 6 sejumlah 55.6\%, sebagian besar responden berusia 20-22tahun sebanyak $74.1 \%$, sebagian besar responden memiliki uang saku dibawah 1.5 juta sebanyak $94.4 \%$.

Berdasarkan Tabel 2 didapatkan bahwa sebagian besar responden semester 2 jarang mengkonsumsi makanan bergizi $52 \%$, sebagian besar responden berusia 20-23 tahun jarang mengkonsumsi 
makanan bergizi sebanyak 60\%. Hampir

mengkonsumsi makanan yang bergizi

seluruhnya responden yang memiliki uang $97 \%$.

saku dibawah 1.5 juta jarang

Tabel 2. Tabulasi silang konsumsi makanan yang bergizi hari dengan semester, usia, dan

uang saku

\begin{tabular}{lcccccccccccccccccccc}
\hline & \multicolumn{1}{c}{ Semester } & \multicolumn{11}{c}{ Usia } & \multicolumn{11}{c}{ Uang saku } \\
\hline Konsumsi gizi & 4 & $\%$ & 6 & $\%$ & 8 & $\%$ & thn & $\%$ & thn & $\%$ & 25 & $\%$ & thn & $\%$ & jt & $\%$ & jt & $\%$ \\
Jarang & 18 & 52.9 & 15 & 44.1 & 0 & 0 & 4 & 11.8 & 27 & 79 & 3 & 8.8 & 0 & 0 & 33 & 97 & 1 & 3 \\
Sering & 9 & 30 & 19 & 63.3 & 2 & 6.6 & 2 & 6.6 & 20 & 67 & 6 & 20 & 2 & 7 & 28 & 93.3 & 2 & 6.7 \\
Selalu & 16 & 37.2 & 25 & 58.1 & 2 & 4.6 & 4 & 9.3 & 32 & 74 & 6 & 14 & 0 & 0 & 40 & 93 & 3 & 7 \\
\hline
\end{tabular}

Tabel 3. Tabulasi silang konsumsi sayuran buah tiap hari dengan semester, usia, dan uang saku

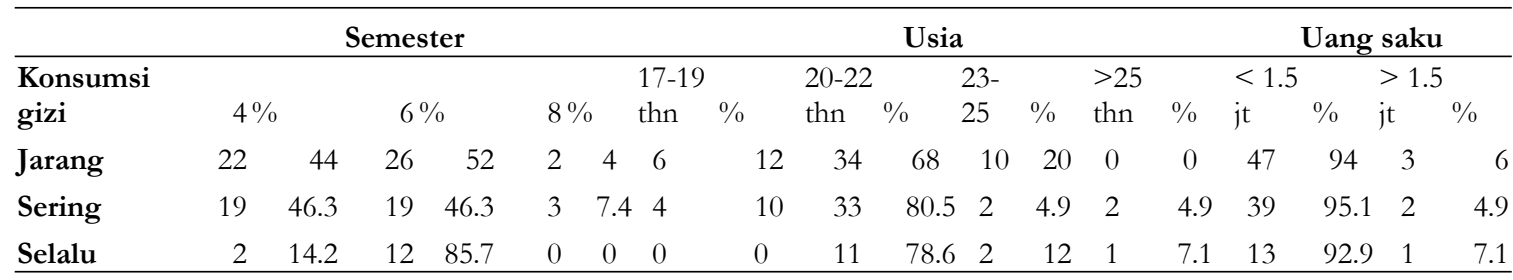

Berdasarkan Tabel 3 didapatkan bahwa sebagian besar responden semester 6 jarang mengkonsumsi sayuran buah setiap harinya sebanyak $52 \%$. Sebagian besar responden berusia 20-23 tahun jarang mengkonsumsi sayuran buah setiap harinya sebanyak 68\%. Hampir seluruhnya responden jarang mengkonsumsi sayuran buah setiap hari memiliki uang saku kurang dari 1.5 juta sebanyak $94 \%$. Tabel 4. Tabulasi silang konsumsi vitamin dengan semester, usia, dan uang saku

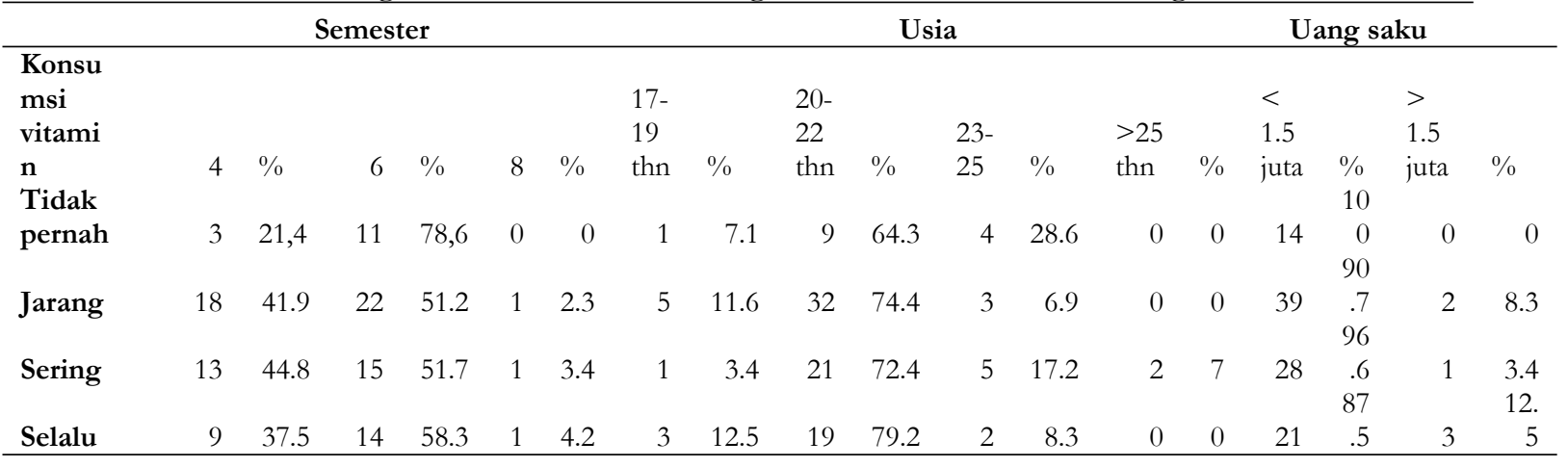

Berdasarkan Tabel 4 didapatkan bahwa sebagian besar responden semester 6 jarang mengkonsumsi vitamin sebanyak $51.2 \%$, sebagian besar responden berusia 20-22 tahun mengkonsumsi vitamin $74.4 \%$. Hampir seluruhnya responden memiliki uang saku $<1.5$ juta jarang mengkonsumsi vitamin. Diketahui bahwa hampir setengahnya responden mengkonsumsi vitamin yang jarang sebanyak 41orang (38.0\%). 


\section{PEMBAHASAN}

\section{Konsumsi Makanan yang Bergizi}

Hasil penelitian menyatakan bahwa hampir setengahnya responden semester 2 jarang mengkonsumsi makananbergizi. Makanan yangbergizi disini berupa makanan yang terdiri dari nasi, buah, sayuran, dan lauk pauk. Berbeda dengan penelitian bahwa pola konsumsi makanan pada mahasiswa sebagian besar kategori cukup (Dwira, 2017). Setara hasil penelitian pada mahasiswa kesehatan berupa setengahnya memiliki pola makan salah (Husnah, 2012), berbeda penelitian Mustathi'atun Niswah (2016) menyatakan pola makan mahasiswa rata-rata 49,93 tergolong kriteria sedang artinya konsumsi makanan bergizinya cukup.

Hasil penelitian ini bertentangan dengan teori asupan makanan bergizi, terdiri dari zat gizi terdiri dari enam macam yaitu :protein, lemak, mineral vitamin, air, dan karbohidrat (Devi, 2010). Karbohidrat memiliki fungsi berupa sumber energi tubuh, selain itu membantu pengaturan dalam memetabolisme protein. (Arisman, 2010). Karbohidrat sebagian disimpan menjadi bentuk glikogen di hati dan juga di jaringan otot, sebagiannya disimpan menjadi cadangannya energi di jaringan lemak (Almatsier, 2011). Asupan tinggi lemak dan karbohidrat akan meningkatkan resiko obesitas dan peningkatan kadar gula darah (Muscogiuri, Barrea, Savastano, \& Colao, 2020), jika kebiasaan berlanjut berupa penyakit paruparu, jantung, dan diabetes. Komorbid penyebab komplikasi dan kematian pada penderita covid-19 yang positif (Wu, et al., 2020), anjuran disaat fase karantina covid-19 dengan konsumsi makanan yang mengandung sintesis melatonin dan serotonin (Muscogiuri, Barrea, Savastano, $\&$ Colao, 2020).

Hasil penelitian ini berbeda penelitian tentang asupan zat makro berupa kurang asupan energi 92.3\%, cukup asupan protein $63.4 \%$, kurang asupan karbohidrat $92.3 \%$ dan kurang asupan lemak 86.53\% (Cornia dan Adriani, 2018). Berbeda penelitian Putri, Sugini, Cintari (2018) bahwa asupan zat gizi makro lebih (karbohidrat, energi, lemak dan protein) sebanyak $62 \%, 54.4 \%, 62 \%, 64.4 \%$, berbeda penelitian Halimah (2014) bahwa tingkat konsumsi energi cukup sebanyak 14 orang (33,3\%), tingkat konsumsi lemak kurang sebanyak 15 orang $(35,7 \%)$. Beda hasil penelitian Hidayat (2016) menyatakan konsumsi makanan yang beresiko masih cukup tinggi pada 
mahasiswa kampus X..Berbeda pada penelitian Arifin (2015) bahwa sebagian besar pola makan kurang baik pada anak usia 3-5 tahun. Berbeda dengan penelitian Nidayanti (2019) bahwa asupan gizi berupa asupan energi dan protein kurang sebanyak; 77,4\%, dan 48,4\%. Berbeda penelitian Salamah (2019) konsumsi energi kategori cukup 33,3\%, kategori lemak kurang dan baik $(35,7 \%)$ pada atlet taekwondo. beda Aningsih (2011) konsumsi energi baik sejumlah $47 \%$.

Faktor lain yang mempengaruhi konsumsi makanan bergizi karena faktor pengetahuan, responden masih semester 2, pengetahuannya masih rendah. Sesuai teori pendidikan yang tinggi berakibat kecenderungan menerima informasi (Ariani, 2017). Sejalan penelitian Ramadhana (2018) pengetahuan gizi baik pada remaja putri sebanyak 74.5\%. Amrullah, Putra, dan Kahar (2020) bahwa hampir seluruhnya $81.5 \%$ pengetahuan tentang gizi baik pada ibu anak usia 3-5 tahun. Sesuai penelitian Pratiwi (2011) bahwa ada pengaruh signifikan pada faktor predisposisi berupa pengetahuan pada pola makannya siswa. Sejalan dengan penelitian Dewi (2013) tentang hubungan antara pengetahuan gizi, sikap terhadap gizi dengan pola konsumsi didapatkan hubungan positif dengan $r$
0,545. Konsumsi energi baik sebanyak 47 siswa dari 57 sampel (Aningsih, 2013). Amrullah, Putra, dan Kahar (2020) menyatakan $81.5 \%$ pengetahuan tentang gizi baik pada ibu anak usia 3-5 tahun. Setara penelitian ada pengaruh langsung positif pengetahuan gizi terhadap pola makan anak (Myrnawati, Anita, 2016).

Konsumsi makanan yang bergizi berkaitan dengan status gizi seseorang, sehingga pengetahuan responden berhubungan dengan status gizi yang diukur dengan IMT seseorang. Setara penelitian terdapat hubungan positif pengetahuan gizi dengan status gizi, setara dengan Karmila (2019) ada hubungan pengetahuan ibu dengan pola MPASI dengan status nutrisi. Berbeda dengan penelitian Ilham (2019) tidak ada hubungan pengetahuan gizi dengan status gizi. berbeda penelitian Liana, Suharno, Panjaitan (2017) bahwa tidak ada hubungan bermaka antara pengetahuan dengan IMT (Indek Massa Tubuh) dengan uji Chi Square pValue 0.189. Selain pengetahuan, konsumsi makanan bergizi seseorang juga dipengaruhi oleh faktor usia. Sebagian besar responden berusia 20-22 tahun. Sependapat penelian bahwa responden yang berusia 21-25 tahun sebanyak 25 orang (37,3\%) (Roring, Posangi, Manampiring, 2020). Setara 
dengan penelitian Husnah (2012) usia responden $<24$ tahun hampir setengahnya 18 orang (38\%), dan pada usia $62,96 \%$ memiliki pola makan yang salah dibanding dengan usia $>24$ tahun.

Faktor uang saku juga berpengaruh pada konsumsi makanan bergizi responden. Teori yang menyatakan konsumsi pangan dipengaruhi oleh sosial ekonominya (Sulistyoningsih, 2011). Sosial ekonomi dilihat dari uang sakunya. sehungga pembelian makanan yang bergizi dengan kualitas dan kuantitasnya menjadi rendah. Penelitian setara dengan adanya hubungan antara pendapatan keluarga dengan status gizi pada anak dengan $p$ value 0,012 (Putri, 2015). Setara dengan penelitian (Wulanta, Amisi, Punuh, 2019) bahwa terdapat hubungan pendapatan keluarga dengan status gizi usia anak 2459 bulan dengan $p$ value 0.034 pada 21 responden. Setara hasil penelitian Myrnawati, Anita, (2016) bahwaada pengaruh langsung positif status ekonomi dengan pola makan anak. Setara penelitian Sebataraja, Oenzil, Asterina (2014)didapatkan tingkat sosial ekonominya baik maka status gizinya baik dan kurang berupa $84.2 \%$ dan $6 \%$, sedangkan tingkat sosial ekonomi rendah diperoleh status gizi baik dan kurang berupa $15,7 \%$ dan $0 \%$ pada murid SD di area pusat kota.

\section{Konsumsi sayuran buah setiap hari}

Hasil peneitian diperoleh sebagian besar responden berupa semester 6 jarang mengkonsumsi sayuran buah setiap harinya. Berbeda dengan penelitian Bahira (2012) bahwa 77,1\% konsumsi sayurnya kurang, sebanyak 92,1 \% kurang asupan buah pada remaja dewasa. Arisman (2012) membuktikan kecenderungan remaja dewasa kurang mengkonsumsi buah dan sayur. Bertentangan dengan teori untuk memenuhi mengkonsumsi sayur dan buah sebagai syarat pemenuhan menu gizi seimbang(Mitchell, 2012), salah satunya banyak makan sayuran dan cukup buahbuahan (Izwardy, 2019).

Konsumsi sayuran buah setiap hari dipengaruhi faktor pengetahuan, mahasiswa semester 6 pengetahuannya lebih baik, terkait lama studi. Setara penelitian tidak ada hubungan antara tingkat pengetahuan gizi dengan konsumsi makanan yang berserat (Zuharia, 2013).Usia responden sebagian besar pada penelitian ini 20-22 tahun. Usia tersebut belum memiliki cukup pengalaman. Setara penelitian usia 21-22 
sebanyak 46,1\% yang menjadi responden pada penelitian (Cornia, I A, Adriani, M 2018).

Uang saku responden penelitian ini hampir seluruhnya $<1,5$ juta. Uang tersebut berada di bawah UMR kota, menyebaban prioritas dalam memenuhi konsumsi makanannya sesuai dari penelitian Dwira (2017) menyatakan responden kadang-kadang, sarapannya di kantin menunya gorengan (bakwan, mendowan, dan tahu bakso. Sulistyoningsih (2011) mengemukakan faktor sosial ekonomi yang cukup dominan dalam mempengaruhi konsumsi pangan adalah pendapatan keluarga dan harga, dalam hal ini berupa uang saku. Hasil penelitian ini bertentangan dengan teori Kemenkes (2020) kecukupan sayur dan buah untuk cegah tertular covid-19, makanan yang segar yang tidak diolah setiap hari (Giakoumis, 2020). Sesuai penelitian tidak ada hubungan antara asupan folat dengan fungsi kognitif pada lansia (Rahmawati, Pramantara, dan Purba, 2012).

\section{Konsumsi Vitamin}

Hasil penelitian didapatkan bahwa hampir setengahnya responden semester 6 berarti sudah 3 tahun berada pada atmosfir kampus, terpapar informasi mengenai vitamin. Vitamin meliputi : A, B1, B6, C, $\mathrm{D}, \mathrm{E}, \mathrm{K}$, dll. bertentangan dengan teori bahwa kegunaan vitamin $\mathrm{C}$ saat pemindahan zat besi dari plasma ke hati dari bentuk transferin ke ferinitin (Almatzier, 2009), mereduksi zat besi dari bentuk feri ke fero di usus yang berakibat mudah diabsorbsi, sekaligus meningkatkan $4 \mathrm{x}$ lipat absorbsinya zat besi jika bercampur dengan vitamin $\mathrm{C}$ (Almatsier, 2009). Menurut Almatsier (2011) mineral dan vitamin contohnya pada sayur dan buah merupakan zat-zat organikkompleks sangat kecil yang dibutuhkan. Peran nutrisi dalam pertahanankan tubuh terhadap virus berupa mengkonsumsi berbagai jenis vitamin dan mineral meliputi :Vitamin A, B, C, D, E, asam lemak omega-3 (EPA dan DHA), selenium, seng, besi, tembaga (Zhang, Liu,2020, Stephensen dan Zunino. Dalam: Ross, Caballero Cousins, Tucker, Ziegler, 2020) Vitamin berpengaruh terhadap sistem imun, vitamin A berperan pemeliharaan sel epitel berfunsi dalam imunitas nonspesifik, vitamin $\mathrm{C}$ sebagai antioksidan yang berperan dalan penetralisir radikal bebas, vitamin $\mathrm{E}$ sebagai antioksidan yang mempertahankan integritas membran (Siswanto, Budisetyawati, Ernawati, 2013). 
Sesuai penelitian Adhini, (2011) bahwa kecukupan vitamin A dan C tergolong normal pada siswa atlet. Dewi dan Wirjatmadi (2017) konsumsi vitamin tidak mencukupi pada atlet sebanyak 90\%. Sukmajati (2015) kurang asupan vitamin B1, B6, C sebanyak 97,2\%, 58.3\%, 94.4\%. Sesuai penelitian Utami, Juniarsana (2013) bahwa reponden mengkonsumsi vitamin $\mathrm{A}, \mathrm{C}$ dan $\mathrm{E}$ didalam suplemennya sebanyak $20 \%$, $40 \%$ dan $80 \%$. lebih tinggi pada atlet sepakbola konsumsi vitamin Cnya sebesar 70\% AKG (2014), lebih tinggi lagi pada atlet Wushu sebesar 96.2\% (normal) (Mutahaya, 2008), berbeda penelitian Rahmawati, Pramantar, dan Purba (2012) bahwa asupan vitamin B6, C, dan E yang kurang pada lansia sebanyak 37.4\%, $21.2 \%$, dan $37.4 \%$, Berbeda dengan pemberian vitamin A $69.1 \%$ tidak diberikan pada anak balita (Fithiyana, 2018).

Faktor lain yang mempengaruhi konsumsi vitamin berupa uang saku. Rendahnya konsumsi tersebut dipengaruhi oleh faktor daya beli. Berbeda dengan penelitian menyatakan $50 \%$ responden uang saku rendah pada mahasiswa (Hidayat, 2016). Berbeda penelitian Suci (2011) mahasiswa memiliki uang saku lebih dari nilai tengah 700 ribu lebih banyak 52\% pada 65 orang.

\section{KESIMPULAN}

Hasil penelitian ini adalah hampir setengahnya responden sesmester 2 jarang mengkonsumsi makanan berigizi, hampir setengahnya responden berusaia 20-22 tahun jarang mengkonsumsi makanan berigizi, hampir setengahnya responden memiliki uang saku $<1.5$ juta jarang mengkonsumsi makanan berigizi, hampir setengahnya responden sesmester 6 jarang mengkonsumsi sayuran buah setiap harinya, hampir setengahnya responden berusaia 20-22 tahun jarang mengkonsumsi sayuran buah setiap harinya, hampir setengahnya responden memiliki uang saku $<1.5$ juta jarang mengkonsumsi sayuran buah setiap harinya, hampir setengahnya responden semester 6 jarang mengkonsumsi vitamin, hampir setengahnya responden berusia 20-22 tahun jarang mengkonsumsi sayuran buah setiap harinya, hampir seluruhnya responden memiliki uang saku $<1.5$ juta jarang mengkonsumsi vitamin.

\section{SARAN}

Peneliti berikutnya hendaknya meneliti korelasi konsumsi sayuran buah serta vitamin dan mineral dihubungkan dengan 
kejadian kelainan gangguan tubuh sebagai dampaknya ketidakcukupan pemenuhan konsumsi tersebut.

\section{REFERENSI}

Almatsier, S. (2009). Prinsip Dasar Ilmu Giz̨i. Jakarta: Gramedia Pustaka Utama.

Almatsier, S. (2011). Gizi Seimbang dalam Daur Kehidupan. Jakarta: Gramedia Pustaka Utama.

Alwarawrah Y, Kiernan K, MacIver NJ. (2018) Changes in Nutritional Status Impact Immune Cell Metabolism and Function.FrontImmunol. 9:1055. https://www.ncbi.nlm.nih.gov/pmc Larticles/PMC5968375/pdf/fimmu09-01055.pdf

Amrullah, A, Putra, A T A, Kahar, A A D A (2020). Deskripsi Status Gizi Anak Usia 3 Sampai 5 Tahun pada Masa Covid 19 MURHUM : Jurnal Pendidikan Anak Usia Dini 1 (2), 1627https://murhum.ppjpaud.org/ind ex.php/murhum/article/view/3/2

Andhini, R.A. (2011). Hubungan Antara Asupan Zat Gizi Dan Komposisi Lemak Tubuh Dengan Kapasitas Dya Tahan Tubuh Atlet Di Sekolah Atlet Ragunan Jakarta (Skripsi, Institut Pertanian Bogor, Bogor). Diakses dari http://repository.ipb.ac.id/jspui/bits tream/123456789/53489/10/ I11 raa.pdf.

Aningsih,dkk.(2013)Hubungantingkatpen getahuandantingkatkonsumsienergi,p roteindenganstatusgizisiswaSMPNeg eri3JorongKabupatenTanahLaut.Jurk essia,IV(1),20-

25.https://journal.stikeshb.ac.id/ind ex.php/jurkessia/article/view/5/4

Ariani, (2017). Ilmu Ggizi. Yogykarta: Nuha Edia
Arifin, Z. (2015) Gambaran Pola Makan Anak Usia 3-5 Tahun Dengan Gizi Kurang Di Pondok Bersalin Tri Sakti Balong Tani Kecamatan Jabon Sidoarjo, (Online), (http://journal.umsida.ac.id/files/3. Zainul Arifin.pdf),

Arisman. (2010) Gizi Dalam Daur Kehidupan. Jakarta: Buku Kedokteran EGC.

Arisman. (2012). Gizi Dalam Daur Kebidupan. Jakarta : Buku Kedokteran EGC.

Aritonang, Evinaria. (2012). Pola Konsumsi Pangan, Hubungan dengan Status Gizi Dan Prestasi Belajar Pada Pelajar SD di Daerah Endemik GAKI Desa Kuta Dae Kecamatan Kerajaan Dairi Propinsi Sumatra Utara. Skripsi. Fakultas Kesehatan Masyarakat Universitas Sumatra Utara.

Ayres, J. S. (2020). Surviving COVID-19: A disease tolerance perspective. Science Advances. 10.1126.

Bahria. (2012)Hubungan antara pengetahuan, gizi, kesukaan dan faktor lain dengan konsumsi buah dan sayuran pada remaja di 4 SMA di Jakarta Barat. Skripsi FKM UI.

Chan, J. F.-W., Yuan, S., kok, K.-H., To, K. K.-W., Chu, h., Yang, j.Yuen, K.Y. (2020). A familial cluster of pneumonia associated with the 2019 novel coronavirus indicating personto-person transmission: a study of a family cluster. Lancet, 514-523.

Cornia, I A, Adriani, M (2018) Hubungan antara asupan zat gizi makro dan status gizi dengan kebugaran jasmani mahasiswa UKM taekwondo. Amerta nutr 2 (1), 90-96 https://ejournal.unair.ac.id/AMNT/article/vi ew/7846/4622

Dewi, K I, Wirjatmadi, R B (2017) Hubungan kecukupan vitamin $\mathrm{c}$ dan zat besi dengan kebugaran jasmani atlet pencak IPSI Lamongan. Media Giri Indonesia, vol. 12(2), 134 
140https://ejournal.unair.ac.id/MGI/article/view $\angle 5111 / 4787$

Dewi, S.R (2013) Hubungan Antara Pengetahuan Gizi, Sikap Terhadap Gizi Dan Pola Konsumsi Siswa Kelas Xii Program Keahlian Jasa Boga di SMK negeri 6 Yogyakarta.Skripsi Fakultas Teknik Universitas Negeri Yogyakarta

Devi, N. (2010). Nutrition and Food, Jakarta : PT. Kompas Media

Dwira, D H (2017) Hubungan pola konsumsi makanan dengan status gizi mahasiswa semester IV jurusan DIV bidan pendidik di Universitas 'Aisyiyah Yogyakarta. Skripsi Universitas 'Aisyiyah

Fithriyana. (2018).hubungan pengetahuan ibu tentang vitamin a dengan pemberian vitamin a pada balita i desa kuantan sako tahun 2016 jurnal doppler universitas pablawan tuanku tambusai vol 2 (1), 50-57

Giakoumis A (2020) A useful health \& nutrition short guide for the COVID-19 pandemic version 2 (30 Maret 2020) Thalassemia International Federation.

Halimah, N, Rosidi, SU, YN. (2014). Hubungan Konsumsi Vitamin C Dengan Kesegaran Jasmani Pada Atlet Sepakbola di Pusat Pendidikan dan Latihan Olahraga Pelajar Jawa tengah Jurnal gizi universitas mubammadiyah semarang 3(2)

Hidayat, A (2016) Hubungan konsumsi makanan berisiko dan aktivitas fisik dengan status gizi mahasiswa kampus x Kedirifurnal Wiyata, 3(2), 140-145.

https://ojs.iik.ac.id/index.php/wiyat a/article/view/83/82

Huang, C., Wang, Y., Li, X., ren, L., Zhao, J., Hu, Y., ... Cao, B. (2020). Clinical features of patients infected with 2019 novel coronavirus in Wuhan, China. Lancet, 497-506.
Hui, D. S., E., I.A., Madani, T.A., Ntoumi, F.,Kock, R., Dar, O., et al. 2020. The Continuing 2019-nCoV epidemic threat of novel coronaviruses to global health-The latest 2019 novel coronavirus outbreak in Wuhan, China. International Journal of infectious Diseaese, 91, 264-66.

Husnah (2012) Gambaran pola makan dan status gizi mahasiswa kuliah klinik senior (KKS) di Bagian Obsgyn RSUD dr. Zainoel Abidin Banda Aceh Jurnal kedokteran syiah kuala volume 12 (1), 23-30. http://www.jurnal.unsyiah.ac.id/JKS /article/view/3491/3244

IlhamD.(2019). Hubungan pengetahuan gizi dan asupan zat gizi karbohidrat, protein, lemak, zat besi, dan vitamin C) dengan status gizi mahasiswi Tingkat I Program Studi Gizi Di Stikes Perintis Padang Tahun 2019.Jurnal Kesehatan Saintika Meditory. 2(1): 81-92.

Izazi, F, P, A K, (2020) Hasil Responden Pengetahuan Masyarakat Terhadap Cara Pengolahan Temulawak (Curcuma Xanthorrbiza) dan Kencur (Kaemferia galanga) Sebagai Peningkatan Imunitas Selama COVID-19 dengan Menggunakan Kedekatan Konsep Program Leximancer, Journal of Pharmacy and Science. 5 (2):93-97

IzwardyD.2019.Buku Panduan Untuk Siswa: Aksi Bergizi, Hidup Sehat Sejak Sekarang untuk Remaja Kekinian. Jakarta: Kementerian Kesehatan RI. https://www.unicef.org/indonesia/s ites/unicef.org.indonesia/ files/202001/Aksi-Bergizi-Siswa-2019.pdf

KarmilaAR.(2019).Hubungan pengetahuan ibu tentang pola pemberian makanan pendamping ASI dengan status gizi bayi 6-24 bulan di Wilayah Puskes-mas 
Petumbukan Desa Nagarejo.[Skripsi]. Medan: Politeknik Kesehatan Medan. http://repo.poltekkes-

medan.ac.id/jspui/bitstream/123456

789/1525/1/KTI\%20RETNO\%20

AYU\%20KARMILA.pdf

Kementrian kesehatan RI. 2020. Panduan gizi seimbang pada masa pandemic covid-19" lindungi keluarga.

LianaAE,Soharno,Panjaitan AA.(2017). Hubungan antara pengetahuan tentang gizi seimbang dengan Indek Masa Tubuh pada mahasiswa. Jurnal Kebidanan.7(2):132-9.

https://media.neliti.com/media/pub lications/265363-hubungan-antarapengetahuan-tentang-gizib4a39282.pdf

LiuM,HeP,LiuHG,etal.(2020).Zhonghuajie HeHeHuXiZaZhi.;43(0):E016.doi:10. 3760/cma.j.issn.10010939.2020.0016

Mitchell,GemmaL,etal.(2012). Parental Influences on Children's Eating Behaviour and Characteristics of Successful Parent-Focussed Interventions. Appetite 60:85-94

Moehji.(2009). Ilmu Gizi 2 Penanggulangan Gizi Buruk Jakarta:Papas Sinar.

Muscogiuri,G., Barrea,L.,Savastano,S.,\& Colao,A. (2020). Nutritional recommendations for CoVID-19 quarantine. European Journal of Clinical Nutrition: 74:850-851 https://www.nature.com/articles/s4 1430-020-0635-2.pdf.

Muntahaya. (2008). Hubungan Tingkat Konsumsi dan Status Giæi dengan Kesegaran Jasmani Pada Atlet Wushu di Wisma Wushu JawaTengah. Skripsi. UNDIP.

Mustathi'atun, Niswah. (2016). Hubungan antara pola makan seharihari dan gaya hidup sehat dengan prestasi belajar mahasiswa pendidikan biologi UIN Walisongo Semarang. Skripsi. http://eprints.walisongo.ac.id/5931/ 1/123811054.pdf
Myrnawati, Anita. (2016). Pengaruh pengetahuan gizi,status sosial ekonomi, gaya hidup dan pola makan terhadap status gizi anak (Studi Kausal di Pos PAUD Kota Semarang Tahun 2015) Jurnal pendidikan usia dini 10(2),213-232 http://journal.unj.ac.id/unj/index.p hp/ipud/article/view/134/91

NidayantiS.(2018). Hubungan tingkat pengetahuan, asupan gizi, aktivitas fisik terhadap status gizi atlet sepak bola PS Kerinci Tahun. [Skripsi]. Padang: Program Studi S1 Gizi Sekolah Tinggi Ilmu Kesehatan Perintis Sumbar, 2019. http://repo.stikesperintis.ac.id/327/ 1/TUGAS $\% 20$ COPI $\% 20 S K R I P S I$ $\% 20 \mathrm{~K}$

Nurwidyastuti, D. (2012). Hubungan konsumsi zat gizi, status gizi, dan faktor-faktor lain dengan status kebugaran jasmani mahasiswa departemen arsitektur Fakultas Teknik Universitas Indonesia (Skripsi, Universitas Indonesia, Depok).

Pratiwi, R. (2011). Analisis factor predisposisi, factor pendukung dan factor pendorong terhadap pola makan pada siswi SMA Yayasan

Putri, NN, Sugini, PPS, Cintari L. (2018). Gambaran pola konsumsi zat gizi makro dan tekanan darah pada lansia di Desa Sibanggede, Kecamatan Abiansemal, Kabupaten Badung Jurusan Gizi Poltekkes Kemenkes Denpasar.7(3),92-102 http://ejournal.poltekkesdenpasar.ac.id/index.php/JIG/articl e/view/JIG07306/pdf

Rahmawati, A Pramantara, IDP, Purba, MR. (2012). Hubungan asupan zat gizi mikro dengan fungsi kognitif pada lanjut usia Asupan zat gizi mikro dengan fungsi kognitif pada lanjut usia Giri klinik Indonesia 8(4),95-201. 
https://jurnal.ugm.ac.id/jgki/article $\angle$ view/18218/11661

Ramadhana C. (2018). Hubungan aktivitas fisik, pengetahuan gizi dan body image dengan status gizi pada remaja putrid di SMK Negeri 6 Sukoharjo. [Skripsi]. Surakarta: Program Studi Ilmu Gizi Fakultas Ilmu Kesehatan Universitas Muhammadiyah.

http:/ / eprints.ums.ac.id/68852/3/H ALAMAN\%20DEPAN.pdf

Roring, MG, Posangi, J, Manampiring, AE. (2020). Hubungan antara pengetahuan gizi, aktivitas fisik, dan intensitas olahraga dengan status gizi Jurnal Biomedik.12(2):110-116

Salamah,R, Kartini, A, Rahfiludin, M.Z. (2019). Hubungan asupan zat gizi, aktivitas fisik, dan persentase lemak tubuh dengan kebugaran jasmani. Media Kesehatan Masyarakat Indonesia. 18(2),14-18.

https://ejournal.undip.ac.id/index.p $\mathrm{hp} / \mathrm{mkmi} /$ article/view/23140/1509 $\underline{1}$

Sebataraja, LR, Oenzil F, Asterina. (2014). Hubungan status gizi dengan status sosial ekonomi keluarga murid sekolah dasar di Daerah Pusat dan Pinggiran Kota Padang Jurnal Kesehatan Andalas.3(2),182-187 http://jurnal.fk.unand.ac.id/index.p $\mathrm{hp} / \mathrm{jka} /$ article/view/81/76

Siswanto, Budisetyawati, \& Ernawati, F. (2013). Peran beberapa zat gizi mikro dalam imunitas. Girii ndon, 36(1):5764.

https://www.persagi.org/ejournal/i ndex.php/Gizi Indon/article/view/ $\underline{116 / 113}$

Stephensen $\mathrm{CB}$ dan Zunino SJ. Nutrition and the immune system. Dalam: Ross AC, Caballero B, Cousins RJ, Tucker KL, Ziegler TR, (2014) editor. Modern Nutrition in Health and Disease. Edisi ke-11. Baltimore: Lippincott Williams \&
Wilkins:601-

10https://jhu.pure.elsevier.com/en/ publications/modern-nutrition-inhealth-and-disease-eleventh-edition.

Suci, S P 2011 Faktor-faktor yang berhubungan dengan pola makan mahasiswa kesehatan masyarakat Fakutas kedokteran dan ilmu kesehatan Universitas islam negeri syarif Hidayatullah Jakarta.Skripsi

Sukmajati,RP. (2015). Hubungan asupan zat gizi mikro dan komposisi lemak tubuh dengan tingkat kebugaran mahasiswa di UKM sepak bola UNY Universitas Muhammadiyah Surakarta Skripsi http://eprints.ums.ac.id/36460/1/N ASKAH $\% 20$ PUBLIKASI J3101310 13.pdf

Sulistyoningsih.(2011). Giz̨i untuk kesehatan ibu dan anak. Yogyakarta: Grahallmu

Susilo, A., Rumende, C. M., Pitoyo, C. W., Santoso, W. D., Yulianti, M., Herikurniawan, . . . Yunihastuti, E. (2020). Coronavirus disease 2019: tinjauan literatur terkini. Jurnal Penyakit Dalam Indonesia, 7.(1), 45-67.

Utami, AP, Juniarsana, IW. (2013). Gambaran tingkat pengetahuan dan tingkat konsumsi vitamin (A,C,E) pada ibu-ibu yang mengkonsumsi suplemen di Lala studio. Skala Husada 10(2), 159-166. http://poltekkesdenpasar.ac.id/files/JSH/V10N2/Ar is $\% 20 \mathrm{Prasetya} \% 20 \mathrm{Utami1}, \% 20 \mathrm{I} \% 20$ Wayan\%20Juniarsana2\%20JSH $\% 20$ V10N2.pdf

Wu, C., Chen, X., Cai, Y., Xia, J., Zhou, X., Xu, S., . . . Song, Y. (2020). Risk factors associated with acute respiratory distress syndrome and death in patients with coronavirus disease 2019. Pneumonia in Wuhan, China. JAMA Intern Med180(7):934943.Retired from 
https://www.nature.com/articles/s4 1430-020-0635-2.pdf

Wulan, I. G., \& Agusni, I. (2015). Penggunaan imunomodulator untuk berbagai infeksi virus pada kulit. Berkala ilmu kesehatan kulit dan kelamin.27(1), 63-69. file:///C:/Users/Seto/Downloads/ 1554-2913-1-SM\%20(1).pdf

Wulanta E, Amisi M D, Punuh M I (2019), Hubungan antara status sosial ekonomi dengan status gizi pada anak usia 24-59 bulan Di Desa Kima Bajo Kecamatan Wori Kabupaten Minahasa Utara. Jurnal KESMAS 8(5), 34-41

ZhangL, LiuY. (2020). Potential interventions for novel corona virus in china: asystematic review $J$ Med Virol. 10:1002 https://www.ncbi.nlm.nih.gov/pmc Larticles/PMC7166986/pdf/JMV92-479.pdf

Zuhaira.(2013). Hubungan tingkat pengetahuan gizi dengan konsumsi makanan berserat pada siswa MAN 3 Rukoh Banda Aceh. Skripsi Banda Aceh Universitas Syah Kuala 